\title{
Readiness factor identification Bandung city MSMEs use blockchain technology
}

\section{Ayu Endah Wahyuni*, Anita Juraida, Asep Anwar}

Department of Industrial Engineering, Universitas Widyatama, Jl. Cikutra No. 204A, Bandung 40125, Indonesia

\section{ARTICLE INFORMATION \\ Article history: \\ Received: November 28, 2020 \\ Revised: January 13, 2021 \\ Accepted: January 19, 2021}

Keywords:

MSMES

TRI

TAM

Technology

Blockchain

\section{A B S T T R A C T}

MSMEs in Indonesia are expected to be able to face competition in the era of industrial revolution 4.0. However, there are many problems and obstacles in competitiveness, especially facing global competition, including access to the capital, access to information and technology, access to organization and management, and access to business networks and partnerships. Besides, it is often difficult for them to get additional capital through banks or other lenders to increase their business scale. Moreover, a lack of financial and digitalliteracy causes the low validity of MSMEs' data to lenders. The adoption of blockchain technology is one of the considerations to minimize these MSMEs problems. Meanwhile, this technology is still relatively new to be applied to MSMEs but positively impacts the future. This study aims to measure and analyze MSMEs' readiness in using blockchain technology on a business scale with the TRAM model. This model integrates the Technology Readiness Index (TRI) and Technology Acceptance Model (TAM) models. This study aims to test several variables, including TRI, perceive ease of use, perceive ease of usefulness, attitude toward, and intense use of blockchain technology. Data processing uses the partial least square path modelling (PLS-PM) method. The results showed that TRI was significant on perceived ease of usefulness and perceived ease of usefulness. Then, perceive ease of use is significant towards perceive ease of usefulness and intention to use. Besides, perceive ease of usefulness is significant for attitude. The attitude toward variable is significant for the intention to use in the acceptance of blockchain technology.

*Corresponding Author

Ayu Endah Wahyuni

E-mail: ayu.endah@widyatama.ac.id

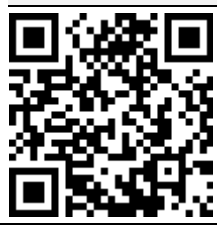
This is an open-access article under the CC-BY-NC-SA license.

\section{INTRODUCTION}

The development of MSMEs in Indonesia is expected to face competition in the era of industrial revolution 4.0. Increased productivity in MSME products provided the most considerable contributi- on to the Indonesian economy by $98.7 \%$ and domestic labour sources by $89.27 \%$ [1]. However, there are many problems and obstacles to be competitive, especially facing global competition in the ASEAN Economic Community (AEC), 
including access to and an accumulation of capital, access to information and technology, access to organization and management, as well as access to business networks and partnerships. The fundamental problem that must be resolved and prioritized is financial management [2]. Therefore, MSMEs must strive to improve competitiveness through financial management by utilizing the latest technology. In addition, Micro, Small and Medium Enterprises (MSMEs) often experience difficulties in obtaining additional capital through banks or other lenders to increase business scale.

According to YLKI (Indonesian Financial Institutions Foundation), this is due to the low level of digital financial literacy in Indonesia, which is around $38.03 \%$, which causes the low validity of data provided by MSMEs to lenders [3]. In addition, according to the Governor ofBank Indonesia, almost $90 \%$ of business actors are unable to manage financial resources [4]. Furthermore, according to the Ministry of Cooperatives and SMEs in Indonesia, the role of business actors connected to digital platforms is still low, around $16 \%$ of the 10.2 million MSMEs in Indonesia [5]. Thus, the digital technology approach is expected to help MSMEs owner manage their finances well. Therefore, technological innovation is needed to facilitate MSMEs in making transactions [6].

This is one of the practical technological innovations is applying blockchain technology to MSMEs in Indonesia as access to new funding for MSME players, especially from banks that have been difficult to obtain so far. Blockchain can be a distributed system database that records transacttional data or other cryptographically secured information and governed by consensus [7]. Additionally, blockchain technology has been used as supply chain management in Italian SMEs in the Agricultural Sector. This technology can increase transparency and supply chain tracking in MSMEs, but with a different implementation framework when used in large companies [8].

There are four main factors of blockchain [9], namely blockchains that are designed to be distributed and viewed across networks to encourage data-sharing businesses and are ideal for multiorganizational business networks. Second, the blockchain is digitally computerized, and agreements are made between participants and stored on the blockchain. Third, before making a transaction, there is an agreement between all the parties involved that the transaction is valid. It can prevent inaccurate or fraudulent transactions from the database. Fourth, the stored data is not deleted and its immortality gated (data immortality). Therefore, MSMEs need to understand cloudbased blockchain development platforms and tools when considering blockchain [10].

Blockchain technology can solve the problems experienced by MSMEs and consumers in transacting through the marketplace. In Indonesia today, problems that oftenoccur in the marketplace include: $28.3 \%$ of goodsnot received, $15.3 \%$ difficulty refund, $12.8 \%$ transaction system, $12.8 \%$ fraud, $5.1 \%$ server system, account hijacking 2.5\% (YLKI) [11]. With the application of blockchain in the marketplace, it can guarantee marketplace data, business credi- bility, modernization of a customer, seller, supplier relationships through Smart contracts, cost efficiency, and the role of intermediaries, increasing profits and competitiveness. In addition, the ease of verification of transactions, recording transacttion data, business activities, transactions processing, and documentation [12]. Therefore, the blockchain system's presence provides new opportunities for Indonesia's business actors to optimize their business through transaction security, eco-friendliness, cost efficiency, and competitiveness. Therefore, MSMEs need to be educated about blockchain technology for business, development and globally [13]. Furthermore, the application of blockchain technology will provide convenience for MSMEs and the public in payment transactions through digital media [14].

Therefore, this study aims to analyze and measure MSMEs' readiness in using Blockchain Technology through the TRAM model. This model is an integration of the TRI (technology readiness index) and TAM (technology acceptance model) models [15]. The TR (technology readiness) model refers to the readiness of individuals to adopt new technologies. The technology readiness index has been used to identify the readiness for implementing IoT in MSMEs. This finding shows that respondents are quite optimistic about the benefits of IoT. Still, the lack of innovation to pioneer an introduction suggests that MSMEs need more information and training to increase knowledge in the use of IoT. [16]. Meanwhile, TAM (technology acceptance model) describes the acceptance of technology by individuals based on the benefits and ease of use [15]. Based on previous research, the technology acceptance model can be used to identify andanalyze MSMEs on the use of digital media for communication on 
commercial, ethical and social responsibility issues, as well as the pace of technological innovation, and examine the perceived Use and convenience of digital media for stakeholder engagement [17].

Meanwhile, TR (technology readiness) has four main factors: optimism, innovativeness, discomfort, and insecurity [18]. The TAM (technology acceptance model) includes Attitude, perceived ease of use, and perceived usefulness [19]. This dimension is a major factor for individuals in understanding technology acceptance [20].

TRI, which has been integrated with TAM, shows that technology readiness is related to technology acceptance, which is very important for understanding technology adoption [21]. The TRAM model has been applied to determine airline passengers' level of technological readiness and its impact on adopting cellular service technology in the South African aviation industry [22]. In order to ensure the adoption of mobile self-service technology in the airline industry, it is necessary to reveal consumer preparedness and adoption behaviour towards the technology. In addition, the TRAM model is used to examine the relationship between customer technology readiness, technology of acceptance, and satisfaction withtechnology that is generally available in the hotel business [23]. This research model was adopted from research [21], [22] and [23]. This research model will measure the readiness of MSMEs in the acceptance of blockchain technology through the TRI (technology readiness index) variable. Then, testing between TRI variables with the TAM (technology acceptance model) model involves the variables. Therefore, the integrated model between TRI and TAM (TRAM) in this study is expected to contribute to the development of MSMEs in preparing for blockchain technologyadoption (Fig. 1).

This study consists of five variables, including the TRI (technology readiness index) variable, perceive ease of Use (PEOU), perceived ease of usefulness technology (PU), attitude toward (ATT), and intention to use (USE). The research variables become constructs in the preparation of research hypotheses (Fig. 2).

H1 : TRI has a positive impact on Perceive Ease of Use (PEOU) on Blockchain Technology?

H2 : TRI has a positive impact on Perceive Ease of Usefulness (PU) on Blockchain Technology?

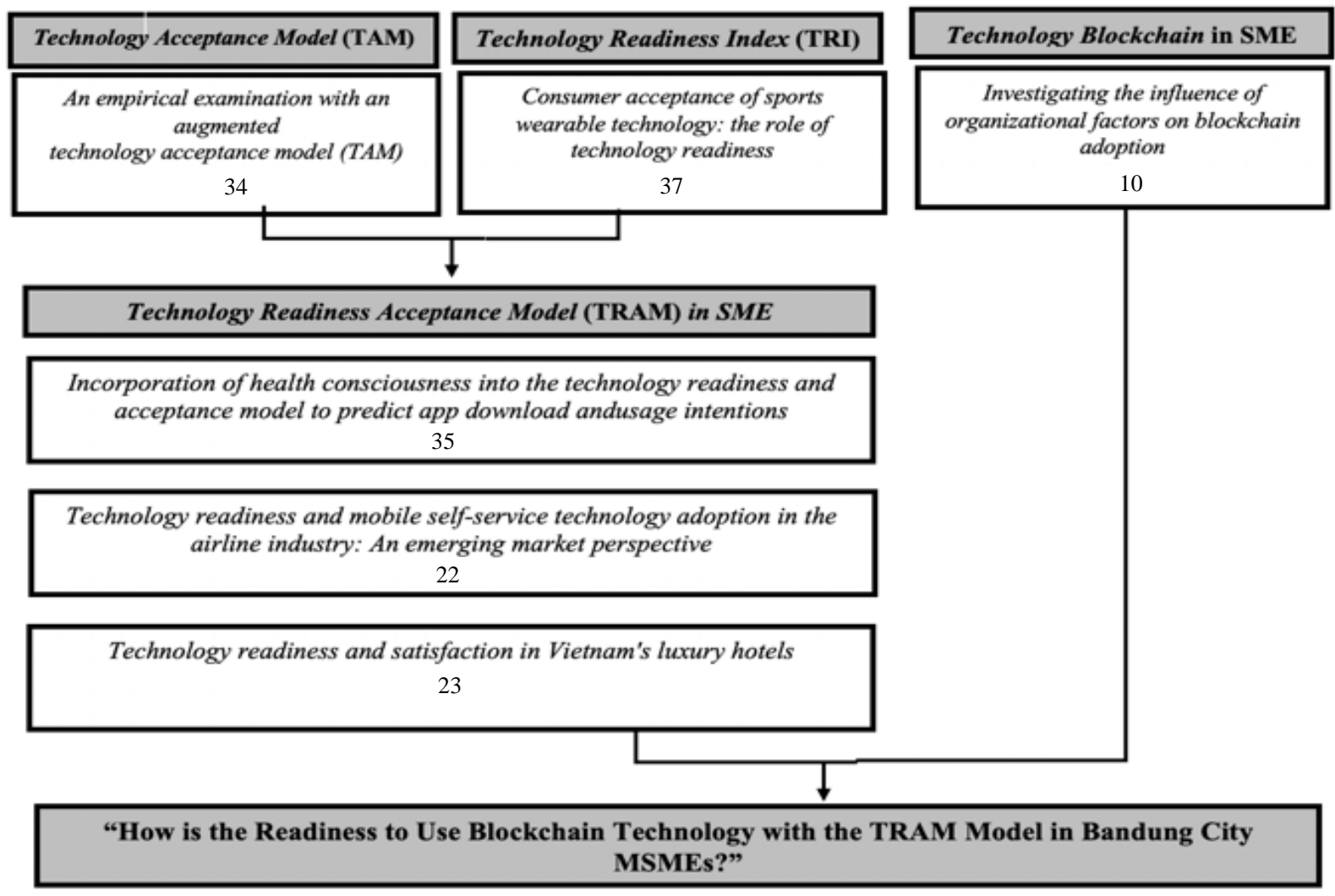

Fig 1. State of the art 
In previous observations, business players manually record transactions, lack transparency, lack efficiency and security in the transaction process, and obstacles in business processes. Several studies have evaluated the advantages of blockchain technology in business. A decentrallized blockchain's characteristics, good speed, guaranteed security, and transparency make this technology necessary for business actors to manage their business [24]. Previous research evaluating the usefulness and acceptance of information and communication technology with an innovative approach to individuals will likely accept technology.

Therefore, TR can influence individuals in accepting new technology [15], [24]. Therefore, TRAM becomes the basic model in this research. Thus, individuals will tend to think of blockchain technology as an innovation that offers convenience in transactions. Optimism is a positive perception of technology that believes that technology provides convenience, flexibility, and efficiency to life [18]. Optimistic individuals will focus on the acceptance of new technology [24]. Thus, individuals will be optimistic that the blockchain network will be easy to apply to businesses and easy to use by business people in transactions. Innovative individuals positively perceive new technology, although the technology benefits and potential are not yet known [25]. In addition, innovation can be defined as a positive attitude in risk-taking, openness, create- vity, and leadership in individuals using new technology [26], [27].

Therefore, innovative business people will consider blockchain technology valuable and easy to use to support business processes, with all the advantages offered by blockchain technology. On the other hand, individuals who feel the uncomfortable with new technology will have anxiety about using it. Therefore, it will negatively affect the perceived ease and benefits of using the technology [28]. Furthermore, individuals who experience problematic discomfort will feel that technology will be difficult to master [25]. Thus, the inconvenience of using the blockchain system will negatively affect business actors' perception regarding the ease and usefulness of using blockchain technology in their business.

Scepticism towards technology is a distrust of technology's ability to work properly [18]. In addition, some individuals do not believe in new technology's security, thus negatively perceiving the convenience and perceived benefits offered by technology [29]. Thus, business actors or individuals who believe that blockchain technology provides security guarantees will believe in the benefits of using this technology.

H3 : Perceive Ease of Use (PEOU) on Blockchain Technology positively impacts Perceived Ease of Usefulness (PU) on Blockchain Technology?

H4 : Perceive Ease of Use (PEOU) on Blockchain Technology positively impacts Attitude Toward (ATT) Using Blockchain Technology?

H5 : Perceive Ease of Usefulness (PU) on Blockchain Technology positively impacts Attitude Toward (ATT) on Blockchain Technology?

H6 : Attitude Toward (ATT) Using Blockchain Technology positively impacts Intention to Use Technology Blockchain (USE)?

H7 : Perceive Ease of Use (PEOU) on Blockchain Technology positively impacts Intention to Use Technology Blockchain (USE)?

H8 : Perceive Ease of Usefulness (PU) on Blockchain Technology positively impacts Intention to Use Technology Blockchain (USE)?

The TAM (technology acceptance model) model can estimate an individual's acceptance of technology use. There are two fundamental factors in the TAM model, namely, perceived ease of use (PEOU) and perceived ease of usefulness (PU) [19]. PU has an influence on the subjective perception of technology users to improve performance by using this technology. Then, the PEOU relates to individual expectations of the ease of using this technology [29]. The TAM model is most often used as a theoretical framework for predictingindividual acceptance of technology [30].

The Perceive ease of usefulness (PU) is one of theTAM model variables, one of the most vital indicators in technology adoption. Moreover, the factors influencing the acceptance of new technology vary widely with the target context and audience [31]. The perceive ease of use (PEOU) is a less powerful predictor than the perceive ease of usefulness (PU) in accepting or adopting new technology. However, the ease with which individuals use technology is very important, so that they tend to adopt this technology [32]. 
Attitude toward (ATT) is an individual's Attitude in responding well. The role of technology influences the intention and behaviour of individuals in adopting technology [33]. Therefore, individuals are involved in the use of technology. This construct leads to individuals who will adopt technology soon [32], [34].

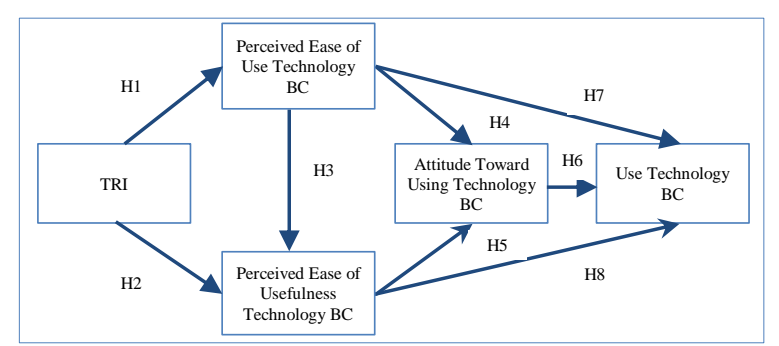

Fig 2. The proposed research model

\section{RESEARCH METHODS}

This research consists of several stages. They first determined the research topic, namely regarding the Acceptance of Blockchain Technology at Bandung City MSMEs. Second, literature study to understand the problems associated with this research and produce a state of the art (Fig. 1). This stage resulted in the TRAM (Integration of TRI and TAM) Model [22], [23], [35]. Third, the research model's development is carried out in several stages, including preparing elements of the research model, operationalizing variables and preparing statement items, and preparing 8 (eight) research hypotheses. Fourth, data collection and processing using SPSS 23.0 and SmartPLS software. The Fifth, descriptive analysis of demography on MSME actors and analysis of research hypotheses regarding the readiness to accept blockchain technology by MSMEs.

Several stakeholders are involved if blockchain technology is applied in the online marketplace, including MSMEs, customers, and suppliers. MSMEs involved in using blockchain technology should understand digital technology and use the marketplace as a marketing platform. The object of this research is SMEs in the city of Bandung that use a marketplace or online store as a place for sales transactions. Business people's experience in using a marketplace or online shop indicates that they already understand how to operate digital techno- logy. Then, the MSMEs, which is the object of this research, consists of several sectors, including culinary, fashion, automotive, electronic, service, furniture, agriculture, and shoes. These business actors already understand the technology and digital transactions, so blockchain technology will provide new knowledge and hopefully make it easier for them to use this technology.

The data collection technique was carried out through a structured questionnaire consisting of five parts to collect primary data. The first part is demographic data on MSME actors, including gender, business line, and workers. Then, Part 2 deals with constructs related to readiness to use blockchain technology. Finally, the questionnaire is developed based on literature related to readiness to use blockchain technology in the second part.

Each question on the questionnaire is measured based on a Likert scale with a scale of "1" (strongly disagree) until a scale of "5" (strongly agree). The distribution of questionnaires online via google docs (email) obtained 44 responses, and offline visiting the UMKM centre in the city of Bandung obtained 122 responses. Survey data collection was carried out for one month from November 1 2020, to November 302020.

Data processing in this study uses SPSS version 23.0 and PLS (partial least square) to Analyze data. This study analyzes the TRAM model and tests the hypothesis using the PLS approach (Fig. 3). The level of reliability was checked based on the coefficient of cronbach alpha and composite reliability (CR) at the level of 0.70 [31]. In addition, convergent validity is acceptable if the mean-variance rate is extracted (AVE) and item loading is 0.50 or higher [36].

Table 1. Measurement model

\begin{tabular}{cccc}
\hline Constructs & CR & $\begin{array}{c}\text { Cronbach's } \\
\text { alpha }\end{array}$ & AVE \\
\hline ATT & 0.904 & 0.858 & 0.702 \\
PEOU & 0.923 & 0.888 & 0.749 \\
PU & 0.940 & 0.915 & 0.796 \\
TRI & 0.796 & 0.768 & 0.272 \\
USE & 0.944 & 0.921 & 0.809 \\
\hline
\end{tabular}

In Table 1 it shows that this research variable produces a reliability value of CR composite greater than 0.90 and Cronbach alpha greater than 0.70 . It explains that the reliability in the construction model of this study is acceptable. However, inthe TRI construct, showing that the AVE value is smaller than 0.50 means that the construct has a question item that must be eliminated because it affects the validity level. While, the hypothsis test shows the results are accepted, significance $=5 \%$ and shows a statistical value greater than 2.0 . 


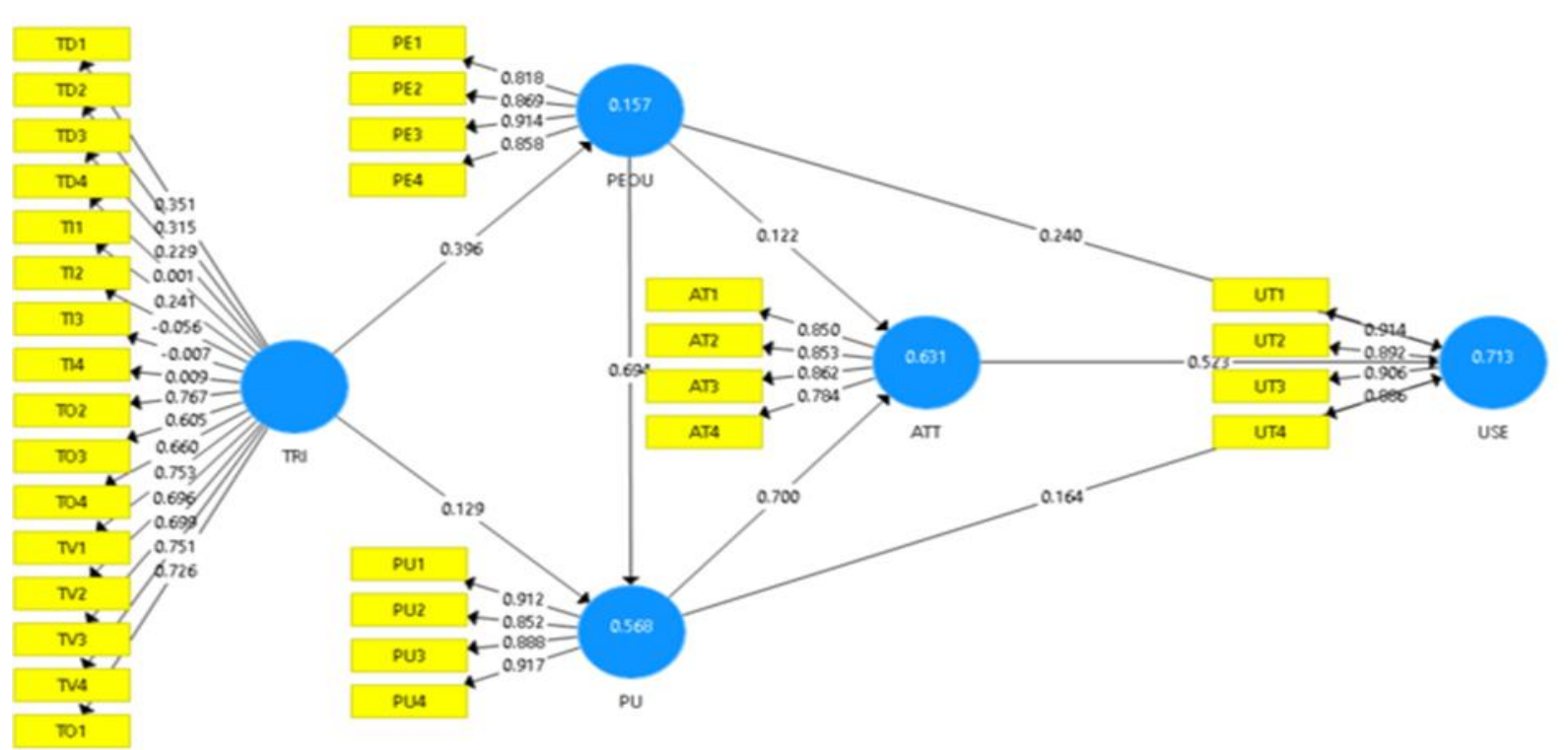

Fig 3. Standardized path coefficients

\section{RESULTS AND DISCUSSION}

The research analysis unit is business actors in Bandung, with a total sample of 166 respondents. The most common type of business is the fashion $(40 \%)$. Respondents were divided into three groups based on the number of employees (Table 2)

Table 2. Demographic profiles and descriptive statistics of respondents

\begin{tabular}{lcc}
\hline \multicolumn{1}{c}{ Characteristics } & Freq & \% \\
\hline Gender & & \\
Male & 87 & 53 \\
Female & 79 & 47 \\
Business Fields & & \\
Culinary & 50 & 30 \\
Fashion & 66 & 40 \\
Automotive & 6 & 4 \\
Electronics & 2 & 1 \\
Service & 21 & 13 \\
Furniture & 4 & 2 \\
Agriculture & 4 & 2 \\
Shoes & 13 & 8 \\
& & 100 \\
Number of employees & & \\
$<10$ persons & 137 & 83 \\
11-50 person & 24 & 14 \\
$>51$ person & 5 & 3 \\
\hline
\end{tabular}

This study aims to test the variables that have been formed into the research hypothesis. Several hypotheses are declared significant based on the tstatistic value. The results of the research hypothesis test can be seen in Table 3 .
Table 3. Structural model

\begin{tabular}{lclcr}
\hline \multicolumn{3}{c}{ Path } & $(\boldsymbol{t})$ & Comments \\
\hline ATT & $\rightarrow$ & USE & 5.941 & Supported \\
PEOU & $\rightarrow$ & ATT & 1.475 & Not Supported \\
PEOU & $\rightarrow$ & PU & 16.265 & Supported \\
PEOU & $\rightarrow$ & USE & 3.126 & Supported \\
PU & $\rightarrow$ & ATT & 10.378 & Supported \\
PU & $\rightarrow$ & USE & 1.838 & Not Supported \\
TRI & $\rightarrow$ & PEOU & 6.604 & Supported \\
TRI & $\rightarrow$ & PU & 2.292 & Supported \\
\hline
\end{tabular}

H1 : TRI has a positive impact on Perceive Ease of Use (PEOU) on Blockchain Technology?

The 1st hypothesis results indicate that TRI is significant and positively impacts perceived ease of use (PEOU), with a t-statistic value of 6.604. Individuals who have experience using higher technology will be more sensitive to technology functionality [37]. The results of this study indicate that individuals' readiness to adopt new technologies has an impact on the ease with which individuals use these technologies. The readiness of business actors to adopt blockchain technology impacts the ease of using this technology in their business.

H2 : TRI has a positive impact on Perceive Ease of Usefulness (PU) on Blockchain Technology?

The second hypothesis results indicate that TRI is significant and positively impacts The perceived ease of usefulness (PU). The significance value is 2.292 . Individual readiness in 
adopting new technology affects individuals in utilizing these technologies to improve their performance. In addition, business actors ready to adopt blockchain technology will impact how to use this technology to advance their business.

H3 : Perceive Ease of Use (PEOU) on Blockchain Technology positively impacts Perceived Ease of Usefulness (PU) on Blockchain Technology?

The 3rd hypothesis results indicate that the perceive ease of use (PEOU) is significant and positively impacts the perceived ease of usefulness (PU). The significance value is 16.265. Personal knowledge about the usefulness of technology systems will impact perceptions about the ease of using technology [25]. Therefore, businessactors predict that blockchain technology providesmany benefits for the progress of their business. Thus, the perpetrator feels confident in the ease ofuse. In previous research, that can apply TAM inthe context of other technology services. In addition, the early use of new technology in individuals who take advantage of the learning ability factor and understand the functionality and use of these technologies [38].

H4 : Perceive Ease of Use (PEOU) on Does Blockchain Technology have a positive impact on Attitude Toward (ATT) Using on Blockchain Technology?

The 4th hypothesis results indicate that perceive ease of use (PEOU) is not significant for attitude toward (ATT) Using on Blockchain Technology based on the value of 1.475 from the $t$ statistic. Individuals perceive the level of ease in using technology as ease of use by individuals [25]. This study explains that the ease with which businesses understand and use the blockchain system in the future is still unpredictable. It is because the understanding of the use of technology by business actors is still low. In previous research, attitudes influence the intention to use services on internet banking technology [39]. Likewise, several other studies have shown that attitude variables impact $\mathrm{PU}$ and PEOU on individual intentions to use technology services [39], [40].

H5 : Perceive Ease of Usefulness (PU) on

Does Blockchain Technology have a positive impact on Attitude Toward (ATT) on Blockchain Technology?

The 5th hypothesis results show that perceive ease of usefulness (PU) is significant and positively impacts attitude toward (ATT) on blockchain technology. It can be seen from the $t$ statistic value of 10.37. The advantages and beliefs felt by individuals in using technology can improve performance [41]. This study indicates that the blockchain technology system can increase the business productivity, transaction efficiency and make it easier to manage work. The ease and benefits of blockchain technology are predicted to influence business actors to use this technology in the future.

H6 : Attitude Toward (ATT) Using on Does Blockchain Technology have a positive impact on Intention to Use Technology Blockchain (USE)?

The 6th hypothesis results show that attitude toward (ATT) is significant and has a positive impact on Intention to use technology blockchain (USE), with a statistical t statistical significance value of 5.941. The belief in doing specific actions produces certain things [42]. These indicators in this study refer to a positive attitude and interest in business actors regarding block- chain technology in the future.

H7 : Perceive Ease of Use (PEOU) on Does Blockchain Technology have a positive impact on Intention to Use Technology Blockchain (USE)?

The 7th hypothesis results show that perceived ease of use (PEOU) is significant and positively impacts intention to use technology blockchain (USE), with a significant value of 3.126. Previous research with the context of banking technology revealed that individuals could feel the ease of using this technology, making it easy for individuals to operate it. If technology is easy to use, it is considered more beneficial and accepted by users [39].

H8 : Perceive Ease of Usefulness (PU) on Does Blockchain Technology have a positive impact on Intention to Use Technology Blockchain (USE)?

The 8th hypothesis results indicate that perceive ease of usefulness (PU) is not significant to Intention to use technology blockchain (USE) with a statistical $t$ value of 1.838 . In previous studies, the TAM model has a positive relationship felt by individuals towards perceived usefulness and behavioral intention to use technology [19]. However, in this study, the perceived usefulness 
and behavioural intention to use blockchain technology are insignificant. It is because technology has never been applied in Indonesia. Thus, business actors have not been able to predict the benefits and use in the future. Meanwhile, in other technological contexts, such as internet banking, it is proven that $\mathrm{PU}$ has a positive influence on attitudes and intentions [39].

\section{CONCLUSION}

The results of the study concluded that the technology readiness index (TRI) had a positive impact on (PEOU) and Perceive Ease of Usefulness (PU). Then, perceive ease of use (PEOU) has a positive impact on the perceived ease of usefulness (PU) and intention to use (USE). Then, perceive ease of usefulness (PU) positively impacts attitude toward (ATT). However, perceive ease of usefulness (PU) and intended use(USE) showed insignificant results. Likewise, perceive ease of use (PEOU) and attitude toward (ATT) are not significant. It is because blockchain technology has not been implemented in MSMEs in Indonesia. So that business actors have not beenable to predict the benefits of and in receiving thistechnology. This research can also be used as a reference related to the readiness of MSMEs in new technology applications. The limitation inthis study is related to the sample used focused onMSMEs in Bandung to not be generalized to all MSMEs in Indonesia. In addition, the limited literature that discusses the application of block- chain technology to MSMEs is very small. There-fore, testing from a sample of MSMEs from different cities and a deeper investigation of MSMEs' readiness to accept new technology, especially blockchain technology.

\section{ACKNOWLEDGMENT}

The author is grateful for the support of the Ministry of Research and Technology / National Research and Innovation Agency for the 2020 Beginner Lecturer Research Grant (PDP) with Contract Number: 002 / SP4 / LP2M-UTAMA / VI / 2020.

\section{REFERENCES}

[1] Kementerian Perindustrian Republik Indonesia, "Transformasi Manufaktur Menuju Industri Maju," 2019. Available: https://kemenperin.go.id/download/23369.

[2] A. H. Adhiningsih, A. A. As-Sahih, and R. Oktamara, "Strategi Pengembangan
UMKM Pedesaan Menuju Entrepreneurs Village Pada Pasar Global,” 2016. Available:

https://www.esaunggul.ac.id/wpcontent/uploads/2017/01/Strategi-

Pengembangan-UMKM-PedesaanMenuju-Entrepreneurs-Village-PadaPasar-Global.pdf.

[3] M. Simanjuntak and A. N. Insyiroh, "Edukasi Konsumen Cerdas di Masa Pandemi Covid-19 pada Masyarakat Kelurahan Joglo, Kota Surakarta," Agrokreatif J. Ilm. Pengabdi. Kpd. Masy., vol. 7, no. 1, pp. 39-47, Mar. 2021, doi: 10.29244/agrokreatif.7.1.39-47.

[4] M. S. Aqida and S. Fitria, "Pengaruh Akses Keuangan Terhadap Pertumbuhan Umkm dengan Moderasi Literasi Keuangan di Kota Semarang," Semarang: Universitas Diponegoro, 2019. Available: http://eprints.undip.ac.id/74791/1/04_AQI DA.PDF

[5] B. Arianto, "Pengembangan UMKM Digital di Masa Pandemi Covid-19," ATRABIS J. Adm. Bisnis, vol. 6, no. 2, pp. 233-247, 2020. Available: https://www.jurnal.plb.ac.id/index.php/atr abis/article/view/512.

[6] A. P. Y. K. Wardani and N. A. S. Darmawan, "Peran Financial Technology pada UMKM: Peningkatan Literasi Keuangan Berbasis Payment Gateway," J. Ilm. Akunt. dan Humanika, vol. 10, no. 2, pp. 170-175, Aug. 2020, doi: 10.23887/jiah.v10i2.25947.

[7] M. Swan, Blockchain: Blueprint for a New Economy. California: O'Reilly Media, 2015. Available: https://books.google.co.id/books?id=RHJ mBgAAQBAJ.

[8] R. Zugaro, "Supply chain management digitalization and SMEs: a study on the implementation of the blockchain technology on an Italian SME in the agricultural sector," Rome: Luiss Guido Carli, 2020. Available: http://tesi.luiss.it/29319/.

[9] P. Dutta, T.-M. Choi, S. Somani, and R. Butala, "Blockchain technology in supply chain operations: Applications, challenges and research opportunities," Transp. Res. Part E, Logist. Transp. Rev., vol. 142, p. 102067, Oct. 2020, doi: 
10.1016/j.tre.2020.102067.

[10] T. Clohessy and T. Acton, "Investigating the influence of organizational factors on blockchain adoption," Ind. Manag. Data Syst., vol. 119, no. 7, pp. 1457-1491, Jan. 2019, doi: 10.1108/IMDS-08-2018-0365.

[11] T. Abadi, "Pengaduan Konsumen dan Kinerja OJK," 2020. Available: http://ylki.or.id/2020/01/pengaduankonsumen-dan-kinerja-ojk/.

[12] A. Atanasovski, M. Trpeska, and Z. Bozhinovska Lazarevska, "The Blockchain Technology and its Limitations for True Disruptiveness of Accounting and Assurance," J. Appl. Econ. Sci., vol. 4, no. 70, pp. 738-748, 2020. Available:

https://www.ceeol.com/search/articledetail id $=936550$.

[13] B. Setiawan and S. De Lagarde, "Edukasi Blockchain sebagai solusi bisnis masa depan bagi pelaku usaha mikro, kecil dan menengah (UMKM)," J. Abdimas Mandiri, vol. 3, no. 2, pp. 131-136, Nov. 2019, doi: 10.36982/jam.v3i2.828.

[14] I. B. P. Bhiantara, "Teknologi Blockchain Cryptocurrency Di Era Revolusi Digital," Semin. Nas. Pendidik. Tek. Inform. (SENAPATI); Vol 9 Pros. Senapati Ke-9 2018, pp. 173-177, Sep. 2018. Available: https://eproceeding.undiksha.ac.id/index.p hp/senapati/article/view/1204.

[15] K.-M. Kuo, C.-F. Liu, and C.-C. Ma, "An investigation of the effect of nurses' technology readiness on the acceptance of mobile electronic medical record systems," BMC Med. Inform. Decis. Mak., vol. 13, no. 1, pp. 1-14, Dec. 2013, doi: 10.1186/1472-6947-13-88.

[16] M. F. A. Zaidi and H. M. Belal, "A Preliminary Study to Understandthe Smes' Readiness on IOT in Malaysia," Int. J. Accounting, Financ. Bus., vol. 4, no. 19, pp. 1-12, 2019. Available: http://www.ijafb.com/PDF/IJAFB-201919-06-01.pdf.

[17] M. A. Camilleri, "The SMEs' technology acceptance of digital media for stakeholder engagement," J. Small Bus. Enterp. Dev., vol. 26, no. 4, pp. 504-521, Jan. 2019, doi: 10.1108/JSBED-02-2018-0042.

[18] A. Parasuraman, "Technology Readiness Index (Tri)," J. Serv. Res., vol. 2, no. 4, pp.
307-320, May 2000, doi: 10.1177/109467050024001.

[19] F. D. Davis, "Perceived Usefulness, Perceived Ease of Use, and User Acceptance of Information Technology," MIS Q., vol. 13, no. 3, pp. 319-340, Sep. 1989, doi: $10.2307 / 249008$.

[20] P. A. Pavlou, "Consumer Acceptance of Electronic Commerce: Integrating Trust and Risk with the Technology Acceptance Model," Int. J. Electron. Commer., vol. 7, no. 3, pp. 101-134, Apr. 2003, doi: 10.1080/10864415.2003.11044275.

[21] H. Hallikainen and T. Laukkanen, "How technology readiness explains acceptance and satisfaction of digital services in B2B healthcare sector?," 2016. Available: https://aisel.aisnet.org/pacis2016/294/.

[22] C. Smit, M. Roberts-Lombard, and M. Mpinganjira, "Technology readiness and mobile self-service technology adoption in the airline industry: An emerging market perspective," Acta Commer., vol. 18, no. 1, pp. 1-12, Sep. 2018, doi: 10.4102/ac.v18i1.580.

[23] L. Van Huy, P. T. H. Nguyen, L. Pham, and R. Berry, "Technology readiness and satisfaction in Vietnam's luxury hotels," Int. J. Manag. Decis. Mak., vol. 18, no. 2, pp. 183-208, 2019, doi: 10.1504/IJMDM.2019.098648.

[24] R. Walczuch, J. Lemmink, and S. Streukens, "The effect of service employees' technology readiness on technology acceptance," Inf. Manag., vol. 44, no. 2, pp. 206-215, 2007, doi: 10.1016/j.im.2006.12.005.

[25] H. Singh, G. Jain, A. Munjal, and S. Rakesh, "Blockchain technology in corporate governance: disrupting chain reaction or not?," Corp. Gov. Int. J. Bus. Soc., vol. 20, no. 1, pp. 67-86, Jan. 2019, doi: 10.1108/CG-07-2018-0261.

[26] Kazım Çelik, "The relationship between individual innovativeness and self-efficacy levels of student teachers," Int. J. Sci. Res. Educ., vol. 6, no. 1, pp. 56-67, 2013. Available: https://www.academia.edu/3430597.

[27] A. F. M. Ayub, S. H. Zaini, W. S. Luan, and W. M. W. Jaafar, "The Influence of Mobile Self-efficacy, Personal Innovativeness and Readiness towards 
Studentsâ\&\#128;\&\#153; $\quad$ Attitudes towards the use of Mobile Apps in Learning and Teaching," Int. J. Acad. Res. Bus. Soc. Sci., vol. 7, no. 14, pp. 364-374, Jan. 2018, doi: 10.6007/IJARBSS/v7i14/3673.

[28] G. Hackbarth, V. Grover, and M. Y. Yi, "Computer playfulness and anxiety: positive and negative mediators of the system experience effect on perceived ease of use," Inf. Manag., vol. 40, no. 3, pp. 221-232, 2003, doi: 10.1016/S03787206(02)00006-X.

[29] S. M. Kim, J.-E. Lee, and C. Park, "An Empirical Study of the Effect of Perceived Risk upon Intention to LBS Use," J. Digit. Converg., vol. 12, no. 12, pp. 119-127, Dec. 2014, doi: 10.14400/JDC.2014.12.12.119.

[30] I. Ajzen and M. Fishbein, Understanding Attitudes and Predicting Social Behavior. Prentice-Hall, $1980 . \quad$ Available: https://books.google.co.id/books?id=AnN qAAAAMAAJ.

[31] M. Chang and W. Wu, "Revisiting Perceived Risk in the Context of Online Shopping: An Alternative Perspective of Decision-Making Styles," Psychol. Mark., vol. 29, no. 5, pp. 378-400, May 2012, doi: 10.1002/mar.20528.

[32] J.-W. Moon and Y.-G. Kim, "Extending the TAM for a World-Wide-Web context," Inf. Manag., vol. 38, no. 4, pp. 217-230, 2001, doi: 10.1016/S03787206(00)00061-6.

[33] P. A. Dabholkar and R. P. Bagozzi, "An Attitudinal Model of Technology-Based Self-Service: Moderating Effects of Consumer Traits and Situational Factors," J. Acad. Mark. Sci., vol. 30, no. 3, pp. 184201, Jul. 2002, doi: 10.1177/0092070302303001.

[34] B. Marakarkandy, N. Yajnik, and C. Dasgupta, "Enabling internet banking adoption An empirical examination with an augmented technology acceptance model," J. Enterp. Inf. Manag., vol. 30, no. 2, pp. 263-294, Jan. 2017, doi: 10.1108/JEIM-10-2015-0094.

[35] M.-F. Chen and N.-P. Lin, "Incorporation of health consciousness into the technology readiness and acceptance model to predict app download and usage intentions," Internet Res., vol. 28, no. 2, pp. 351-373, Jan. 2018, doi: 10.1108/IntR03-2017-0099.

[36] J. F. Hair, Multivariate Data Analysis with Readings. Prentice Hall, 1995. Available: https://books.google.co.id/books?id=vtoK AAAACAAJ.

[37] T. Kim and W. Chiu, "Consumer acceptance of sports wearable technology: the role of technology readiness," Int. J. Sport. Mark. Spons., vol. 20, no. 1, pp. 109-126, Jan. 2019, doi: 10.1108/IJSMS06-2017-0050.

[38] A. I. Canhoto and S. Arp, "Exploring the factors that support adoption and sustained use of health and fitness wearables," $J$. Mark. Manag., vol. 33, no. 1-2, pp. 32-60, Jan. 2017, doi: 10.1080/0267257X.2016.1234505.

[39] I. Bashir and C. Madhavaiah, "Consumer attitude and behavioural intention towards Internet banking adoption in India," $J$. Indian Bus. Res., vol. 7, no. 1, pp. 67-102, Jan. 2015, doi: 10.1108/JIBR-02-20140013.

[40] J.-S. Chiou and C.-C. Shen, "The antecedents of online financial service adoption: the impact of physical banking services on Internet banking acceptance," Behav. Inf. Technol., vol. 31, no. 9, pp. 859-871, Sep. 2012, doi: 10.1080/0144929X.2010.549509.

[41] V. A. Zeithaml, A. Parasuraman, and A. Malhotra, "Service Quality Delivery through Web Sites: A Critical Review of Extant Knowledge," J. Acad. Mark. Sci., vol. 30, no. 4, pp. 362-375, Oct. 2002, doi: 10.1177/009207002236911.

[42] H. A. Riyadh, E. G. Sukoharsono, and Z. Baridwan, "E-banking Implementation and Technology Acceptance in the Rafidain and Rasheed Banks in Iraq: an Employee Perspective," Int. J. Account. Bus. Soc., vol. 23, no. 2, pp. 87-113, 2016. Available:

https://ijabs.ub.ac.id/index.php/ijabs/articl e/view/287. 